\title{
Weed Management in Cowpea-A Review
}

\author{
Taramani Yadav ${ }^{1}$, Nisha, K. Chopra ${ }^{2}$, N. K. Chopra ${ }^{2}$, M. R. Yadav', \\ Rakesh Kumar $^{1}$, D.K. Rathore ${ }^{1}$, P.G. Soni ${ }^{1}$, G. Makarana ${ }^{1}$, A. Tamta ${ }^{1}$, M. Kushwah ${ }^{1}$, \\ H. Ram ${ }^{1}$, R.K. Meena ${ }^{1}$ and M. Singh ${ }^{1}$ \\ ${ }^{1}$ ICAR- National Dairy Research Institute, Karnal, India-132 001 \\ ${ }^{2}$ ICAR-Indian Agricultural Research Institute, Regional station, Karnal, India-132 001 \\ *Corresponding author
}

\section{A B S T R A C T}

\section{Ke y w o r d s \\ Cowpea, Herbicide, Seed quality, Crop rotation, Weed flora, Weed management.}

\section{Article Info}

Accepted:

24 January 2017

Available Online:

10 February 2017
India is the largest producer and consumer of the pulses in world. There is a huge shortage of pulses in the country to meet out the domestic demand especially of vegetarian population. The low production and productivity of pulses under Indian condition is mainly due to several biotic and abiotic constraints. In general, the pulses crops are more susceptible to the stresses including weeds as compare to the cereals and oilseeds. It was widely reported that yield losses due to weeds especially in the pulses are more than the loss caused either by insect-pest or diseases. Besides, pulses crops are treated on low priority compared to the cereals. Little attention has been given in the past by researchers also for developing effective and efficient strategies for weed management in this group of crops. Being a protein rich crop, Cowpeas is one of the most important food legume crops in the arid and semiarid tropics of the world. Due to its drought-tolerant characteristics, cowpea is known to well-adapted to the drier regions of the tropics, where other food legumes do not perform well. It also has the useful ability to fix atmospheric nitrogen through its root nodules. Weeds posses' a severe problem in cowpea production and, if it is not managed with best management practices, can serve as hibernating agent for pests and reduce not only yield but also quality of the seed and fodder yield. Bing a poor competitor with weeds and its cultivation during monsoon season, the cowpea known to infested with a wider range of weeds especially at the initial stage of growth. Based on the location, soil type, verities and agronomic management the reduction in the yield due to weeds in cowpea is in the range of 12.7 as high as $60.0 \%$. Weed control methods employed depends on the nature of the weed problem and the means available with the farmer to control them efficiently. In general, the problem of weed infestation in cowpea is more severe at the initial period (5-8 weeks). Chemical weed control alone or in conjugation with manual weeding is most promising, although there are cultural options like intercropping, crop rotation, closer spacing, tillage, etc. which could reduce the weed infestation in cowpea. Due to its smothering capacity, its intercropping with other legumes and cereals proved to be reducing the problem of the weeds leading to higher grain yield and dry fodder yield than in sole crop. Integration of the components of production technologies enhanced the productivity of cowpea which ultimately resulted into higher net returns to the farmers. Therefore, an attempt has been made in this article to review works done on several aspects of weed management in cowpea (Vigna unguiculata). 


\section{Introduction}

In terms of both area and production of all important pulses grown, India ranks first and contributes about $25 \%$ to the total pulse basket of the world (Choudhary, 2009). This group of crops is known to for their nutritious food, feed and forage as compare to the cereals. Being rich source of nutrients and easiness in their cultivation, pulses still remained as an important integral component of subsistence cropping system since time immemorial in most of the arid and semiarid region of the world (Choudhary, 2013). In India, over a wider range of pulse crops are grown; among the important ones are chickpea, pigeonpea, cowpea, mungbean, urdbean and lentil (Ali and Gupta 2012). The production and productivity of pulses in the world in general and in India particular, continues to be low, as most of them are generally grown in rainfed areas with poor management condition and face various kinds of biotic and abiotic stresses.

In India, production of pulses is around 19.3 million tonnes (ESI 2015) with a very low average productivity of $764 \mathrm{~kg} / \mathrm{ha}$ (Yadav et al., 2016b). Currently, total area under pulses is 26.3 million ha (Choudhary and Suri 2014). Their cultivation over poor, marginal and nutrient deficient soils, unfavourable weather conditions, unavailability of quality seeds, poor socio-economic conditions of the growers, and severe weed infestation especially during mansoon season, poor postharvest handling and inadequate market support are some major constraints in realizing the potential of available technologies for the pulse production (Choudhary, 2013).

Cowpea (Vigna unguiculata) is one of the important legumes which grown extensively under tropical and sub-tropical areas of world (Asia, Africa, Central and South America) (Rathore et al., 2015). Cowpea can make a very important contribution towards livestock fodder on the one hand and supply available nitrogen to the soil on other hand, (Aikins and Afuakwa, 2008). It's a dual-purpose attractive crop particularly in arid and semi arid ecologies of the world. In India, it is cultivated on about $0.5 \mathrm{M}$ ha with an average productivity of $750 \mathrm{~kg}$ seeds/ha (Ahlawat and Shivakumar, 2005). Cowpea is grown throughout the country in small pockets for its food and fodder. The grain contains $20-25 \%$ of protein which is twice the protein content of most cereals (IITA, 2007). It is deep rooted hardy crop with good drought tolerant capacity (Dadson et al., 2003). Being a versatile crop, cowpea can be grown as a sole crop, intercrop, catch crop, relay crop, cover crop and green manure crop, etc., under sequential/mono-cropping in different agro ecological regions of the world.

In the cropping systems of dry regions, pulses such as cowpea is play a key role due to their low input requirements and ability to tolerate drought and consequently perform relatively better than other crops in the fragile and harsh climate prevailing in these regions of the world. Beside as a grain legume cowpea is equally important as a nutritious fodder for livestock because the nutritive value of foliage isvery high and it's free from any type of toxicity (Bimbraw, 2013; Singh and Tarawali, 1997). The real yield limiting factor in cowpea is inadequate source and sinks, limiting quality seed production (Kumar and Sarlach, 2014). Beside these inadequate weed control had also been identified as a major contributory factor for yield gap. Due to its smothering capacity, its intercropping with other legumes and cereals proved to be reducing the problem of the weeds leading to higher grain yield and dry fodder yield than in sole crop which ultimately resulted into higher net returns to the farmers. Therefore, an attempt has been made in this article to review works done on several aspects of weed management in cowpea. 


\section{Benefits of growing cowpea}

Cowpea crop being deep rooted and drought tolerant dual purpose leguminous crop and add significant amount of organic matter/nitrogen to the soil, becomes an integral part of the soils and subsistence crop production system in the arid and semiarid region of the world. Due to aforesaid reasons, cowpea can be grown as a sole crop, mixed crop, intercrop crop under different agroecologies of the world. With the development of short duration cowpea verities and uniform maturity in recent years as a result of long lasting efforts of researchers, its cultivation has now been introduced in irrigated areas under multiple cropping systems especially in north western and central part of India. It has the potential for partial diversification and intensification of the cereal based systems through its cultivation during summer season when field generally left fallow after rabi harvest (Kumar et al., 2015). This group of crops is known fertility building crops and their beneficial effect in improving soil health and sustaining productivity has been widely reported. Being a legume crop, cowpea blessed with a natural character of biological nitrogen fixation that leads to improvement in the soil fertility. Besides, it also known to add considerable amount of organic matter through root biomass and leaf-fall, deep root systems, mobilization of nutrients, protection of soil against erosion and improving microbial biomass, they keep soil productive and alive by bringing qualitative changes in physical(bulk density, water retention capacity, higher hydraulic conductivity), chemical (soil organic carbon, soil reaction, macro and micro nutrient balance)and biological properties (microbial biomass, diversity, function and soil enzymatic activities) (Parihar et al., 2016; Yadav et al., 2016;Ali and Singh, 1997.) As a result of this, the productivity of cereals following a cowpea crop often increases and corresponds to $40-60 \mathrm{~kg} \mathrm{~N}$ equivalent besides increasing the net retunes and lowering the cost of cultivation. In the present scenario of decline in factor productivity (Parihar et al., 2016; Yadav et al., 2016), stagnation in crop yield and depression in farm income (Yadav et al., 2016a), which is posing a serious threat to food security, agricultural sustainability, soil and environmental health and rural agricultural economy in world inclusion of pulses may be adapted as a strategy to reduce the pace of aforesaid factors (Prasad, 2005; Yadav et al., 2012). In nutshell, diversification and intensification of cereal based cropping systems so as to sustain the farm productivity and profitability and farm livelihoods, conserve natural resource-base, and reduce farm and environmental risks, in this context, cowpea provide an excellent opportunity (Aggarwal et al., 2004). In improving soil fertility and system productivity, cowpea was most beneficial followed by pigeonpea and pigeonpea + mungbean. Soybean-wheat system was most productive followed by pigeonpeamungbean-wheat among Kharif pulse based cropping systems.

\section{Weed management in cowpea}

\section{Weed spectrum in cowpea}

The occurrence of weed flora under any crop production system greatly influenced by range of factors such as crop history, soil seed bank, tillage operations, selection of crops, application of chemical fertilizer, irrigation and agronomic practices etc Barralis and Chadoeuf, 1980; Saved et al., 1990). Beside these, the weed control measures (Hass and Streibig, 1982) and environment factors (Schmer and Chilcote, 1969;Chu et al., 1978) also significantly influenced the distribution of weed flora. Weed flora Because it is grown during mansoon season and slow initial growth and sowing at wider spacing, weed 
infestation in cowpea is as severe as in other pulses. Therefore, at the initial period of growth and the cowpea requires more attention towards weed control (Kandasamy, 1999). The problem of weed has been reported more severe during rainy season, as weeds come in 2-3 flushes and growth is very fast, therefore, they compete for light, nutrient and space and are responsible for considerable reduction in crop yield and productivity. Some weed species commonly occurring in the Kharif/wet season pigeonpea are enlisted below. They all may neither be associated to a particular pulse/legume crop nor do all pulses and legumes have all these weeds distributed with them across states/regions of the country. These all factor in bulk have a variable impact on weed flora and their distributions under diverse agroclimatic conditions leads to variable weed problem were reported over the location. For example Tripathi and Singh, 2001 reported that the Dactyloctenium aegyptium (41.8\%), Eleusine indica (15.7\%), Gnaphalium indicum (14.4\%), Cyperus rotundus (12.8\%), Echinochloa crusgalli (8.4\%) and Sorghum halepense $(6.9 \%)$ as major weed flora in cowpea field. Growing cowpea under mix or intercropping also leads to change in weeds and their distribution in this regard Kumaravelu, 2009 reported that when cowpea mix planted with sugarcane, greengram (Vigna radiata L.) infested mostly by grasses like Cynodon dactylon, Cyperus rotundus, Dactylotaenium ageyptium while among the dicots, the predominant ones were Phyllanthus niruri, Amaranthus spp. However, this is an overall distribution of composite culture of weeds in the cowpea during Kharif season. Annual grass weeds: Acrachne racemosa, Commelina benghalensis/ communis/subulata/ nudiflora, Eleusine africanal indica, Setaria viridis/ glaucal verticillata, Echinocloa colona/crusgalli, Rottboellia cochinchinensis (exaltata), Brachiaria spp, Panicum spp,
Dactyloctenium aegyptium, Digitaria sanguinalis/ adscendens. Annual broadleaved weeds: Amaranthus graecizans/hybridus/ viridis/retroflexus, Ageratum conzoides, Bidenspilosa/biternata, Celosia argentea, Chorchoru ssp, Capsella bursa-pastoris, Datura stramonium, Digera arvensis, Euphorbia hirta, Flaveria trinervia, Galinsoga parviflora, Galiuma parine, Guizotia scabra, Heliotropium indicum, Leucas aspera, Malvaprusilal parviflora, Nicandra physalodes, Physalis minima, Phyllanthus niruri, Parthenium hysterophorus, Scoparia dulcis, Solanum nigrum, Sonchus asper/ aleraceous, Tagetes minuta, Trinthema portulacasttrum/ monogyna, Tribulus terrestris, Xanthium strumarium.

Perennial weeds: Grasses: Cynodon dactylon, Plantago lanceolata (simple perennial); Sedges: Cyperu ssp (mainly C. rotundus and $C$. esculentus), Broad-leaved weeds: Convolvulus arvensis, Launae acornuta, Plucheala nceolata and Oxalis latifolia (simple perennial).

\section{Critical period of crop weed competition}

The weed infestation in any crop depends mainly upon the type of tillage, availability of soil moisture and the tilth of the seed bed that performed to make soil environment more favourable for crop growth and development. Weeds were known to compete with the crop for resources such as moisture, nutrient, and light since long and treated as never ending problem. At present, the most commonly employed method to control weed in cowpea weeds are controlled manually, mechanically or chemically. In India, where most of the world's cowpea is grown, produced and consumed, manual and/or mechanical methods, weeds are more common. These practices have certain limitation like nonavailability of labor at right time and 
economics. Weeds control methods vary greatly with the status of agriculture and the nature of the cropping system adopted. Pre emergence applications alone are not sufficient to curtail repeated flushes of weeds during rainy season, which highly necessitates a post-emergence application following preemergence one. Weeds do not cause harm to crops equally all through the growing period. There are certain stages in crop growth cycle when weeds are more damaging to crop growth and yield. Usually early season weed competition is most detrimental to crop and, therefore, early season weed control is indispensable, The critical period of weed competition may be defined as "the short time span in the life-cycle of a crop, when weed causes maximum reduction in its yield or in other words, when weed control measure if adopted may fetch near maximal or maximum acceptable crop yield (Das, 2008)." It is the specific duration of weed-free situation of a crop resulting into near maximal yield, which is sufficiently close or equal to that obtained by the season-long weed-free situation. In agronomic point of view, the critical period with regards to crop weed competition is the time span between early growth during which weeds can grow without affecting crop yield and the point after which weed growth does not affect yield Zimdahl, (1980). Establishment of critical period of crop weed completion is a critical concept for development effective and economical weed in any crop (Sharma et al., 1977). Critical period of crop weed completion may vary from location to location by a number of factors such as agro-climatic conditions, type of soil, season of planting and crop cultivar. A "thumb rule" is that the first one-fourth $\left(1 / 4^{\text {th }}\right)$ to one-third $\left(1 / 3^{\text {rd }}\right)$ period of the total growing duration of a crop, irrespective of growth stages, weed species and environmental (climatic and soil) conditions may be assumed as "the critical period for weed competition." In pigeonpea, initial 6-8 weeks period is the critical period of the crop-weed competition Tripathi and Singh, 2001 reported that critical stage of weed competition in cowpea was 1545 DAS. Similarly, Freitas et al., 2009 evaluated that the critical period in cowpea was 11-35 DAS while Sunday and Udensi, 2013 reported its first 3-4 weeks of crop growth where weeds presence affect crop yield negatively. Contrast to this, Patel et al., 2003 recorded that in cowpea during rainy season, a wide range of weed species compete with the crop just after germination and continue up to harvest. Therefore during this season the whole period of crop growth may be considered as critical period for weed crop competition.

\section{Yield losses due to weeds}

In any crop or cropping sequence the weed density, type of the weeds, their persistence and crop management practices determine the magnitude of yield loss. As cowpea is infested by a variety of weed species that compete with the crop right from germination to harvest, affecting the crop yield, (Yadev et al., 1998). Presence of weeds not only increasing the production cost but they also intensify disease and insect pest problem by serving as alternative hosts. Besides quantitative effects on yield, weeds deteriorate the quality of produce through the physical presence of their seeds and debris. Yield loss in crops due to weeds is influenced by a number of environmental, plant and soil factor and varies across the location due to variability of these factors. Tripathi and Singh, 2001 reported that presence of weeds in cowpea reduced yield by $82 \%$ and significant increase in pod yield was recorded by controlling weeds up to 45 days of sowing. Similarly, Li et al., 2004 reported that yield loss due to weeds was $12.7-60.0 \%$. Likewise, Madukwe et al., 2012 reported that in Nigeria, the presence of weeds caused 53$60 \%$ yield loss in legumes including cowpea. 
Similarly, Freitas et al., 2009 also reported that weed interference in cowpea not only reduced the final stand but also the number of pods per plant, and grain yield up to 90\%.Sunday and Udensi, (2013) reported that control weed growth and/or inadequate weed control in the crop have been reported to account for $40-80 \%$ reduction in grain yield in cowpea.

\section{Methods of weed control in cowpea}

Weed managementaim at not only to achieve per cent weed control but also to create favourable conditions for crop growth (Brar and Walia, 1989). Weed control methods are grouped into Preventive, physical, cultural and chemical.

\section{Preventive and physical options}

Preventive measure of weed control involved a wide range of practices that such as clean cultivation, weed free seed bed, use of clean seeds, use of well decomposed farm yard manure, clean bunds and irrigation channels, tools and farm machinery are some of the fundamental and free of cost practices that need to be followed for successful cultivation of any crop. Besides, destruction of weeds by cutting and removal through hand hoeing, hand pulling, tillage and flooding or desiccation and exhaustion of weeds through burning, soil sterilization and mulching can also be done to control the weed or to reduce their intensity. Manual weed control is the most common method used by farmers in cowpea production. Hand weeding is considered useful because it is not only control the weeds but also improves soil physical conditions. Besides, the practice of hand weeding known to loosens the soil surrounding the rhizosphere of crop plants and thereby enhances crop growth and yield. For example, Ahlawat et al., 2005 reported that one hand weeding at 25 days after sowing
(DAS) resulted in $90 \%$ increase in cowpea yield as compare to weed infested plot in north western Indo-Gangetic Plains of India. Similarly, Dugje et al., 2009 also observed that two hand weeding in cowpea twice, first at 2 weeks after planting, and secondly at 4-5 weeks after planting resulted in comparable yield with chemical weed control. Hand pulling should be carried out in time and early in the crop growth. Weeds in cowpea can be controlled effectively with hand weeding to be done at 3 and 6 weeks after sowing (Anonymous, 2014). However due to frequent rains it becomes difficult to do hand weeding at proper time, furthermore, non-availability of labour for hand weeding is another problem. So there is a need to find effective weed control techniques to keep the weed flora below economic threshold level (ETL). Mulching is very effective against most annual weeds and some perennial weeds such as Cynodon dactylon and Sorghum halepense. In soil solarization, a good land preparation ensuring fine tilth and smooth and even surface of soil reduces air spaces between the polythene film and soil. Surface soil temperature may increase up to $55-60^{\circ} \mathrm{C}$ due to solarization during hot months, which kills weed seeds and vegetative propagules, insects, nematodes and disease pathogens and cause them to die. Solarization for a minimum period of two weeks during May and June is sufficient to control weeds.

\section{Cultural options}

Some cultural practices such as choice of crop species, crop cultivars, planting density, crop geometry, inter cropping, crop rotation, time of sowing; crop rotation, fertilizers and irrigation practices have profound effect on weed suppression. Normally weeds compete with crop plants more severely in early growth stages; therefore, crop planning should be done in such a way that it may boost the early growth and vigor of crop 
plants, which results into a better crop competition with weeds. To reduce the adverse effect of weeds in field crops, select long duration varieties as these varieties grow quickly and produce canopy early, resulting in shading and thus suppress the growth of weeds. If initial big flush of weeds germinating at one point of time is bypassed through manipulation of time of sowing of a crop, a little earlier or later than its normal time of sowing, the crop may germinate and have initial growth under almost weed-free or less weedy environment. Closer spacing (row to row) suppresses the germination and growth of weeds results in keeping the crops free from weeds as weeds get less space, light and nutrients for growth. Crop rotation and intercropping plays a vital role in suppressing the weeds. The possibilities of certain weed species or a group of species occurring is greater if the same crop is grown year after year. In many instances, crop rotation can eliminate or at least reduce weed problems by changing microclimate in each field. The success of rotation systems for weed suppression appears to be based on the use of crop sequences that create varying patterns of resource competition, allelopathic interference, soil disturbance, and mechanical damage to provide an unstable and frequently inhospitable environment that prevents the proliferation of a particular weed species. Crop growth pattern, cultural practices, weed control techniques, type and intensity of tillage for different crops vary in crop rotation and this variation creates a barrier for further proliferation of crop-associated weeds. Crop rotation is highly effective against parasitic weeds such as Striga hermonthica/asiatica, Orobanche ramosa, Cuscuta spp. Results of a literature survey indicate that weed population density and biomass production may be markedly reduced using crop rotation (temporal diversification) and intercropping (spatial diversification) strategies. Significant advances in the design and improvement of weed-suppressive crop rotation and intercropping systems are most likely to occur if three important areas of research are addressed. First, there must be continued attention to the study of weed population dynamics and crop-weed interference in crop rotation and intercropping systems. More information is needed concerning the effects of diversification of cropping systems on weed seed longevity, weed seedling emergence, weed seed production and dormancy, agents of weed mortality, differential resource consumption by crops and weeds, and allelopathic interactions. Second, there needs to be systematic manipulation of specific components of rotation and intercropping systems to isolate and improve those elements (e.g., inter-row cultivation, choice of crop genotype) or combinations of elements that may be especially important for weed control. Finally, the weed-related impacts of combining crop rotation and intercropping strategies should be assessed through careful study of extant, complex farming systems and the design and testing of new integrated approaches. Many aspects of crop rotation and intercropping are compatible with current farming practices and could become more accessible to farmers if government policies are restructured to reflect the true environmental costs of agricultural production (Liebman and Dyck 1993). Intercrops may demonstrate weed control advantages over sole crops in two ways. First, greater crop yield and less weed growth may be achieved if intercrops are more effective than sole crops in usurping resources from weeds or suppressing weed growth through allelopathy. Alternatively, intercrops may provide yield advantages without suppressing weed growth below levels observed in component sole crops if intercrops use resources that are not exploitable by weeds or convert resources to harvestable material more efficiently than sole crops. The nature and magnitude of crop-weed competition 
differs considerably between sole and intercropping systems. Growing of crops in intercropping systems is found more productive particularly under rainfed conditions. More than $70 \%$ area of pulses in India is covered under intercropping systems. Pulses are intercropped with oilseeds, cereals, coarse grains and commercial crops. Cowpea is also inter/mixed cropped with short growing grain legumes. The crop species, population density, sowing geometry, duration, and growth rhythm of the component crops, the moisture and fertility status of soil, and tillage practices are some most important factors that influence weed flora in intercropping systems. Intercropping enhances crop canopy and thus suppresses weeds. Short duration legumes (urdbean, mungbean) when grown with cowpea under intercropping system suppressed weed flora considerably. Highest suppression ability was recorded with cowpea (45.8\%) followed by urdbean $(41.5 \%)$ and mungbean $(38.2 \%)$.

\section{Chemical method}

The progressive modernization of agriculture involving intensive use of herbicide ad chemical weed control gaining popularity in recent years due to lower cost, easy to handle and effectiveness in controlling weeds. Recent trend of herbicide use is to find out an effective measure with low dose herbicide which will not only reduce the total volume of the product but it also makes the application economic. Chemical weed control i.e. use of herbicide proved the most practical, effective and economical means of controlling even unapproachable or in accessible weed or noxious weed. In addition, they reduce drudgery of hand weeding which is labour intensive and time consuming. Herbicides, if used properly, are safe and effective in controlling weeds in cowpea. The choice of herbicide, however, depends on the predominant weed species and the availability of the herbicide. Several reported that chemical weed control employing appropriate herbicides which would be effective at lower dose and also gives economic return is an effective measure for weed control in cowpea. Hanumanthappa, 2012 reported that application of Pendimethalin @ $0.75 \mathrm{~kg}$ a.i./ha as pre-emergence or use of Pendimethalin @ $0.75 \mathrm{~kg}$ a.i./ha pre emergence along with one hoeing at 20-25 DAS gave broad spectrum control of weeds and resulted in higher cowpea seed yield and B:C ratio. Similarly, Usman, 2013 reported that there was significant yield increase of cowpea due to application of Pendimethalin at the rate of $3.5 \mathrm{~L}$ a.i./ha + Hand weeding at 6 weeks after sowing as compare to un weeded control. There are a few reports where chemical weed control using herbicides showed significant effect on growth attributes of cowpea. Madukwe, 2012 reported that chemical weeding at 2-3 leaf stage resulted highest value of plant height, number of pods/plant and test weight as compare to hand weeded cowpea. There are a number of reports on influence of herbicides on yield attributes and crop yield. In this regard Dadari, 2003 and Silva et al., 2003 reported that the use of herbicides in cowpea to control weeds appears to be useful and there was significant increase $(68 \%)$ in grain yield of cowpea due to chemical-weeding at 2 - 3 leaf stage of weeds + hand-weeding at 50 DAS as compare to un-weeded control. Likewise, Madukwe et al., 2012 also concluded that the highest seed yield of cowpea was recorded from plot that received chemical weeding at 2-3 leaf stage of weeds as compare hand weeding at 50 days after planting. Jaibir et al., 2004 reported that Pendimethalin at $1.0 \mathrm{~kg}$ a.i. /ha + hand-weeding at 30 DAS gave the highest cowpea yield and lowest weed density and dry biomass. Madukwe et al., 2012 reported that the highest $(93.0 \%)$ mean germination percentage was recorded from plots that received herbicide at 2-3 leaf stage 
of weed while, the lowest germination percentage $(80.6 \%)$ was recorded from the unweeded check (control) plots in cowpea. The use of herbicides for weed control in cowpea can result in highly effective control and lower production costs, if compared to mechanical control, especially weeding (Fontes et al., 2010). Chemical weed control seems to be cheaper and effective; the overall economics of this practice does justify its general adoption by growers except in area where the labour is cheap and easily available during peak period of farm operations. Patel et al., 2003 reported that Pre-emergence application of pendimethalin at $0.75 \mathrm{~kg}$ a.i./ha + weeding at 5 week after sowing, reported higher grain yield as well as net return compared to weeding alone. Likewise, Hanumanthappa, 2012 also reported that the application of pendimethalin $0.75 \mathrm{~kg}$ a.i./ha as pre-emergence or use of pendimethalin @ $0.75 \mathrm{~kg}$ a.i./ha pre-emergence + one hoeing at 20-25 DAS gave broad spectrum control of weeds and resulted in higher cowpea seed yield, net return and $\mathrm{B}: \mathrm{C}$ ratio as compare to un-weeded control.

\section{Integrated weed management}

Integrated weed management (IWM) is a system approach for maintain the weed population below their economic threshold level by employing all available means of weed control in coordination. Integrated weed management is basically integration of effective, dependable and workable weed management practices such as cultural, mechanical, chemical and biological that can be used economically by the farmers (Pooniya et al., 2012;Pooniya et al., 2014)). Integration of chemical weed control method with hand weeding, application of pendimethalin@2.01 a.i./ha applied at 3 days after planting along with one hand-weeding at 30 DAS resulted in lower weed population and weed dry matter, which enhanced the crop yield in cowpea during rainy season Rao et al., 1992; Mathew and Sreenivasan, 1998, Patel et al., 2003,Parasuraman, 2000). Likewise, Jarbir et al., 2004 reported that pendimethalin $1.0 \mathrm{~kg}$ a.i./ha pre-emregence with one hand weeding at 30 days after of sowing provide effective weed control in cowpea field. Similarly, Madukwe et al., 2012 reported that chemical weeding at 2-3 leaf stage of weed + hand weeding at 50 DAP prove effective weed control method in cowpea field and produced the highest cowpea seed yield. Therefore, good crop husbandry + recommended preplanting or pre-emergence herbicides + one hand weeding to control late emerging annuals as well as perennial weeds, namely Cynodon dactylon, Cyperus rotundus/esculentus can be practised. Among the crop husbandry practices, time and date of sowing, tillage, variety, fertilization, crop rotation, intercropping, pests and diseases control measures are the most important one for them farmers should need to take proper care to achieve good weed control at lower cost.

In conclusion, Weed infestation in cowpea is as severe as in other pulses at the initial period of growth and the crop requires to be kept free from weeds particularly during first 6-8 weeks. Most critical period of competition between weeds and cowpea crop was between 20 and 40 DAS Intercropping enhances crop canopy and thus suppresses weeds. Legumes, viz. urdbean, mungbean, soybean and pigeonpea when grown with cowpea under intercropping system suppressed weed flora considerably. Pendimethalin $1.0 \mathrm{~kg}$ a.i./ha followed by hand weeding at 40 DAS resulted in higher weed control efficiency, yield attributes, forage and seed yield and their quality with higher net returns and $\mathrm{B}: \mathrm{C}$ ratio compared to other herbicidal treatments. An application of pre-emergence pendimethalin $1.0 \mathrm{~kg} / \mathrm{ha}$ and post-emergence application of imazethapyr $0.10 \mathrm{~kg} / \mathrm{ha}$ at $30-35$ DAS has 
been found effective towards weed control in cowpea.

\section{References}

Aggarwal, P.K., Joshi, P.K., Ingram, J.S.I. and Gupta, R.K. 2004. Adapting food systems of the Indo-Gangetic plains to global environmental change: key information needs to improve policy formulation. Environ. Sci. Policy 7:487-498

Ahlawat, I.P.S., and Shivakumar, B.G. 2005. Kharif pulses. In Textbook of Field Crops Production. Dr. R. Prasad (Ed.). New Delhi: Indian Council of Agricultural Research.

Ahlawat, I.P.S., Singh, A. and Saraf, C.S. 1981. It pays to control weeds in pulses. Indian Farming 31(3): 11-13.

Aikins, S.H.M. and Afuakwa, J.J. 2008. Growth and dry matter yield responses of cowpea to different sowing depths. ARPN J. Agri. Biol. Sci., 3(5-6): 50-54.

Ali, M. and Singh, K.K. 1997. Management of pulse crops under intercropping systems. In: Recent Advances in Pulses Research (Eds. AN Asthana and M Ali): Indian Society of Pulses.

Anonymous. 2014. Package of Practices for Kharif Crops of Punjab. Punjab Agricultural University, Ludhiana, India.

Barralis, G. and Chadoeuf, R. 1980.Study of weed dynamics of weed community $\mathrm{I}$. Evalution of the weed flora during the growth cycle of a crop. Weed Res., 20: 231-23.

Bimbraw, A.S. 2013. Production, utilization and conservation of forage crops in India. 1st edition. Jaya Publishing House, Delhi.

Brar, L.S. and Walia, U.S. 1989. Herbicidal control of congress grass, Parthenium hysterophorus. Indian J. Weed Sci., 23(3\&4): 36-38.
Chattha, M.R., Jamil, M. and Mahmood, T.Z. 2007. Yield and yield components of mungbean as affected by various weed control methods under rainfed conditions of Pakistan. Int. J. Agriculture and Biol., 9(1): 114-119.

Choudhary, A.K, Thakur, S.K and Suri, V.K. 2013. Technology transfer model on integrated nutrient management technology for sustainable crop production in high value cash crops and vegetables in NW Himalayas. Communications in Soil Sci. Plant Analysis, 44 (11): 1 684-99.

Choudhary, A.K. and Suri, V.K. 2014. Scaling up of pulses production under frontline demonstrations technology programme in Himachal Himalayas, India. Communication in Soil Science and Plant Analysis, 45 (14):1934-48.

Choudhary, A.K., Yadav, D.S. and Singh A. 2009. Technological and extension yield gaps in oilseeds in Mandi district of Himachal Pradesh. Indian J. Soil Conservation, 37 (3): 224-9.

Chu, G.C., Ludford, P.M., Ozbun, J.L. and Sweet, E.O. 1978.Effect of temperature and competition on the establishment and growth cycle of red root pigweed and common lamb's quarter. Crop Sci., 18: 308-310.

Dadari, S.A. 2003. Evaluation of herbicides in cotton/cowpea mixture in the Northern Guinea Savanah. J. Sustainable Agriculture Environ., 5: 153-9.

Dadson, R.B., Hashem, F.M., Javaid, I., Joshi J. and Allen, A.L. 2003. Response of diverse cowpea genotypes to drought. (CD-ROM) Annual meeting abstracts. ASA, CSSA, SSSA, Madison, WI.

Das, T.K. 2008. Weed Science: Basics and Applications. Jain Brothers Pub. New Delhi. pp. 901-2.

ESI. 2015. The Economic Survey 2014-15. The Economic Survey of India, New Delhi. 
Fontes, J. R. A., Goncalves, J. R. P. and Morais, R. R. de. 2010. Cowpea tolerance to oxadiazon. Indian J. weed sci., 40(1): 110-115.

Freitas, F. C. L. Medeiros, V. F. L. P. Grangeiro, L. C. Silva, M. G. O. Nascimento, P. G. M. L. Nunes, G. H. 2009, Wed interference in cowpea. Indian J. weed sci., 27(2): 241-247.

Hanumanthappa, D. C. Mudalagiriyappa Rudraswamy Kumar, G. N. V. and Padmanabha, K. 2012. Effect of weed management practices on growth and yield of cowpea (Vigna unguiculata L.) under rainfed conditions. Crop Res., (Hisar) 44(1/2): 55-58.

Hass, H. and Streibig , J.C. 1982.Changing pattern of weed distribution as a result of herbicides use and other agronomic factor. In: Herbicides resistance in plants.Pp.57-59 Le Baron H.M. and Gressel, J (Eds.) John

IITA. $2007 . \quad$ Cowpea. www.iita.org/cms/details/cereal_legume saspx $?=a 86 \& 2=63$.

Jaibir, T., Singh, H.B., Vivek and Tripathi, S.S. 2004. Integrated weed management in intercropping of mungbean (Vigna radiate) and cowpea fodder (Vigna unguiculata) with pigeon pea (Cajanus cajan) under western U.P. condition. Indian J. Weed Sci., 36: 133-4.

Kandasamy, O.S. 1999. Effect of herbicides with and without manual weeding on weeds and yield of rainfed pigeonpea (Cajanus cajan L. Millsp.). Legume Res., 22(3): 172-176.

Kumar, B. and Sarlach, R.S. 2014. Economic analysis of foliar applied bio-regulator for seed production in forage cowpea [Vigna unguiculata (L) Walp.] cultivars under Punjab conditions. Society for Science Development in Agriculture and Technology. Progressive Res., 9(1): 12-15.

Kumar, G., Singh, M., Kumar, Rakesh,
Yadav, R.K., Datt, C., Paul, K., Soni, P.G. and Chauhan, A. 2015. Yield and quality of Fodder Turnip as Affected by Nitrogen Application and Weed Management during Winter Lean Periods. Indian J. Animal Nutrition, 32(1): 57-62.

Kumaravelu, G. 2009, Weed flora and the management strategy in intercropping cultivation. Int. J. Plant Sci., (Muzaffarnagar) 4(2): 454-459.

Li et al. 2004. Damage loss and technology of weed in cowpea field, Weed science 2:25-26.

Liebman Matt. and Elizabeth, Dyck. 1993. Crop rotation and intercropping strategies for weed management. Ecol. Applications 3(1): 92-122.

Madukwe, D.K., Ogbuehi, H.C. and Onuh, M.O. 2012. Effect of weed control method on the growth and yield of cowpea (Vigna unguiculata (L) Walp) under Rain- fed condition Owerri. American-Eurasian J. Agriculture and Environment Sci., 12(11): 1426-30.

Mathew, G. and E. Sreenivasan, 1998. Effect of weed control methods on yield and economics of rain-fed and rice fallow summer cowpea. Madras Agri. J., 85: 50-2.

Parasuraman, P. 2000. Weed management in rain fed cowpea (Vigna unguiculata) and greengram (Phaseolus radiatus) under North West Agro climatic zone of Tamil Nadu. Indian J. Agrnomy 45: 732 $-736$.

Parihar, C.M., Yadav M.R., Jat S.L., Singh A.K., Kumar, B., Pradhan, S., Chakraborty, D., Jat, M.L., Jat, R.K., Saharawat, Y.S. and Yadav, O. P. 2016. Long term effect of conservation agriculture in maize rotations on total organic carbon, physical and biological properties of a sandy loam soil in northwestern Indo-Gangetic Plains. Soil and Tillage Res., 161: 116-28. 
Patel, M. M. Patel, A. I Patel I. C. Tikka, S. B. S. Henry, A. Kumar, D. and Singh N. B. (2003). Weed control in cowpea under rain fed conditions. In: Proceedings of the National Symposium on Arid Legumes, for Food Nutrition. Security and promotion of Trade Pp : 203 - 206. Hisar, India, 15 - 16 May, 2002. Advances in Arid Legumes Research.

Pooniya, V., Choudhary, A.K., Sharma, S.N., Bana, R.S., Rana, D.S. and Rana, K.S. 2014. Mungbean (Vigna radiata) residue recycling and varietal diversification for enhanced system productivity and profitability in basmati rice (Oryza sativa)-wheat (Triticum aestivum)-mungbean cropping system. (In) Proceedings of National Symposium on Crop Diversification for Sustainable Livelihood and Environmental Security, held during 1820 Nov., 2014 at PAU, Ludhiana, pp 629-30.

Pooniya, V., Shivay, Y.S., Rana, A., Nain, L. and Prasanna, R. 2012. Enhancing soil nutrient dynamics and productivity of Basmati rice through residue incorporation and zinc fertilization. European J. Agronomy, 41: 28-37.

Prasad, R. 2005. Rice-wheat cropping system. Advances in Agronomy 86:25533914.

Rao, M.R., Shetty, S.V.R., Reddy, S.L.N. and Sharma, M.M. 1992. Weed management in improved rain-fed cropping systems in semi-arid India. In: Renard, C., R.J. Beldt, J. Van den and F. Par, (eds.) Soil, Crop and Water Management Systems for Rain-fed Agriculture in the Sundano Sahelianzone, Pp: 303s-16.

Rathore, D.K., Kumar, R., Singh, M., Meena, V.K., Kumar, U., Soni, P. G., Yadav, T.M. and Makarana, G. 2015. Phosphorus and zinc fertilization in fodder cowpea - A review. Agri. Review 36 (4): 333-338

Saved, K., Torres, L. G., Bermejo, E. H. and Hildago, B. 1990. Influence of environmental factor on the weed flora in crops in Guadalquivir Valley. Weed res., 30:363-374.

Schemer, D. E. and Chilcote, D. O. 1969.Factors influencing persistenc and depletion in buried seed population. A model for analysis of parameter of buried seed persistence and depletion. Crop Sci., 9: 417-19.

Sharma, H. C., Singh, H.B and G.H Friesco. 1977. Weed research . 17: 103-108.

Silva, J.B.F., Pitombeira, J.B., Nunes, R.P. and Pinho, J.L.N. 2003. Weed control in cowpea under no till system. Planta Daninha, 21: 151-7.

Silva, P. S. L., Oliveira, O. F., Silva, P. I. B., Silva, K. M. B. and Braga, J. D. 2009 .Effect of cowpea intercropping on weed control and corn yield. Indian J. Weed Sci., 27(3): 491-497.

Singh, B.B., Tarawali, S.A. 1997. Cowpea and its improvement: key to sustainable mixed crop/livestock farming systems in West Africa. In: Renard, C. (Ed.), Crop Residues in Sustainable Mixed Crop/Livestock Farming Systems. CAB International in Association with ICRISAT and ILRI, Wallingford, UK: 79-100.

Sunday, O. Udensi, U. E. 2013. Evaluation of pre-emergence herbicides for weed control in cowpea (Vigna unguiculata (L.) American J. Experimental Agri., 3(4): 767-779.

Tripathi, S.S. and Singh. 2001. Critical period of weed competition in summer cowpea (Vigna unguiculata L.). Indian J. Weed Sci., 33: 67-8.

Usman, I. 2013. Effect of pre emergence herbicides on weed control and performance of cowpea in Samaru. $J$. Agricultural Sci., (Sri Lanka) 8(2): 76- 
81.

Yadav R.L., Dwivedi, B.S., Prasad, K., Tomar, O.K., Shurpali, N.J. and Pandey, P.S. 2000. Yield trends, and changes in soil organic carbon and available NPK in a long-term ricewheat system under integrated use of manures and fertilizers. Field Crops Res., 68:219-246

Yadav, M.R., Parihar, C.M., Jat, S.L., Singh, A.K., Kumar, D., Pooniya, V., Parihar, M.D., Saveipune, D., Parmar, H. and Jat M L. 2016. Effect of long-term tillage and diversified crop rotations on nutrient uptake, profitability and energetics of maize (Zea mays) in north-western India. Indian J. Agri. Sci., 86(6): 743-9.

Yadav, M.R., Parihar, C.M., Kumar, R., Meena, R.K., Verma, A.P., Yadav,
R.K., Ram H., Yadav, T., Singh M., Jat, S.L. and Sharma A. Performance of maize under conservation tillage 2016a; Int. J. Agri. Sci., 8(39): 1802-1805.

Yadav, T., Chopra, Nisha, K., Chopra, N.K., Kumar, Rakesh, Singh, M., Datt, C., Soni, P.G., Rathore, D.K. and Kumar, S. 2016. Influence of Weed Control Methods on Yield and Quality of Cowpea Fodder. Indian J. Animal Nutri., 33(1):70-74.

Yadev, B.D., Joon, R.K. and Singh, J.V. 1998. Contribution of production factors on growth and seed yield of cowpea under rain-fed conditions. Forage Res., 24: 157-8.

Zimdhal, R.L. 1980. Weed crop compaction. A review Int. Plant protection center Oregon State Univ. Corvallis PP 41-46.

\section{How to cite this article:}

Taramani Yadav, Nisha, K. Chopra, N.K. Chopra, M.R. Yadav, Rakesh Kumar, D.K. Rathore, P.G. Soni, G. Makarana, A. Tamta, M. Kushwah, H. Ram, R.K. Meena, M. Singh. 2017. Weed Management in Cowpea-A Review. Int.J.Curr.Microbiol.App.Sci. 6(2): 1373-1385. doi: http://dx.doi.org/10.20546/ijcmas.2017.602.156 